\title{
Fijian Language
}

National Cancer Institute

\section{Source}

National Cancer Institute. Fijian Language. NCI Thesaurus. Code C153918.

An Austronesian language of the Malayo-Polynesian family spoken by ethnic Fijians as a native language. 